\title{
Islamic Fasting during Ramadan will Negatively Impact on Pandemic of COVID-19 (SARS-CoV-2)
}

\begin{abstract}
Sorush Niknamian*
Military Medicine Department, Liberty University, USA.

ABSTRACT

The aim of this review is to prove Islamic Fasting during COVID-19 pandemic has negative effect on the spreading of the virus. Basically Water makes up about $60 \%$ of one's body weight. Fasting in Islamic religion is to stop drinking and eating any kinds of food/drinks (Water). even a little amount is forbidden during this month (Ramadan) and the duration is almost 29-30 days. In this review, we have mentioned the impact of fasting in causing Organ/Cellular inflammation, dehydration, dampen cellular/body metabolism which reduces producing enough ATP by mitochondrion through citric acid cycle (CAC) which causes body and organ weakness, dizziness, tiredness and reduction in immune system functioning of the body and increasing the amounts of Reactive Oxygen Species in cells that increasing the possibility of contamination the fasted individual to several important diseases. Infectious diseases including microbial/viral diseases, high abnormal heart rate as a result of falling blood volume which put high pressure on heart and worsen heart disease. The humidity and temperature of the environment in spring time is also help spreading viruses including SARS-CoV-2. Based on evidences in this article, Islamic Fasting during the pandemic of COVID-19 will increase the rate of contaminated people.
\end{abstract}

\section{KEYWORDS}

COVID-19, Islamic Fasting, Dehydration, Cellular Inflammation, Immunodeficiency, Water, Histamine, Nerve damage.

Corresponding Author Information

Sorush Niknamian

Military Medicine Department, Liberty University, USA.

Received: March 12, 2020; Accepted: March 28, 2020; Published: April 08, 2020

Copyright: (C) 2020 ASRJS. This is an openaccess article distributed under the terms of the Creative Commons Attribution 4.0 International license.

Citation: Sorush Niknamian. Islamic Fasting during Ramadan will Negatively Impact on Pandemic of COVID-19 (SARS-CoV-2). Med Clin Res Open Access, 2020;1(1):1-5.

\section{Introduction}

Islamic Fasting Explanation

Fasting from sunrise to sunset is obligatory for all adult Muslims who are not acutely or chronically ill, travelling, elderly, pregnant, breastfeeding, diabetic, or menstruating (1). The predawn meal is referred to as suhur, and the nightly feast that breaks the fast is called iftar $(2,3)$. Although fatwas have been issued declaring that Muslims who live in regions with a midnight sun or polar night should follow the timetable of Mecca (4). It is a common practice to follow the timetable of the closest country in which night can be distinguished from day (5-7). The spiritual rewards of fasting are believed to be multiplied during Ramadan (8). Accordingly, Muslims refrain not only from food and drink, but also tobacco products, sexual relations, and sinful behavior (9-10). Devoting themselves instead to prayer, recitation of the Quran (11-12), and the performance of charitable deeds as they strive for purity and heightened awareness of God. During fasting, people are limited to drink water, and kinds of food. This period is from sunrise to sunset (Which at least 8-10 Hours and mostly 15 Hours) for at most 30 days (13-14). 


\section{Discussions}

The main reasons which influences the enhance of epidemic of SARS-CoV-2 during Islamic fasting are: Dehydration (Due to not eating water in a long period of time) of the body and specially cells, reducing the metabolism of the body which is controlled by mitochondria in eukaryotic cells, reducing the immune system function due to tiredness and malnutrition. Over-Praying during Night/Day time which also cause dizziness, nerve damage and lack of sleep period which cause negative impact on immune system (15).

The dehydration process is essentially compounding itself and producing inflammation throughout the body. The body is constantly building itself up and breaking itself down that is a continual cycle. Every cell has its own lifecycle, it is born, dies and is replaced. Inflammation is cytotoxic or can kill cells prematurely. Cellular death is a major contributor to the chronic medical conditions. Dehydration inhibits the effectiveness of one's lymphatic system and allows cellular waste products to linger and create further havoc. Research has found dehydration to have a negative effect on one's brain and can contribute to the development of depression and nerve damage (16). The brain consumes vast amounts of glucose that is delivered via the blood supply. (17). Dehydration affects the amount of overall blood volume that in return affects the brain. Mild to moderate dehydration can also cause headaches, diminish memory and impair one's ability to think clearly. Proper hydration is essential for nerve function throughout the body. Nerves are sensitive and the body places a high priority to their health and maintenance. Once a nerve dies, there is no re-growth within the central nervous system. Micro streams exist along the length of the nerves and transport nutrients along microtubules to where the messages are being transmitted. Dehydration can disrupt these messages, often resulting in the sensation of pain, fatigue, low energy, loss of muscle strength and poor endurance (18).

Histamine is a neurotransmitter that plays a significant role in encouraging water intake during periods of dehydration (19). Elevated levels of histamine can also impact and contribute to asthma, depression and chronic pain (20). These conditions are often treated with anti-histamines and painkillers that essentially turn off signals of thirst. Water makes up about $60 \%$ of one's body weight which cannot be neglected in chronic dehydration (17-20). Chronic inflammation and dehydration during Islamic Fasting can alter one's metabolism and promotes immunodeficiency. The brain and kidneys regulate the amount of water excreted by the body. When the blood volume is low through dehydration, the brain responds by stimulating a hormone that signals the kidneys to reabsorb and recirculate water. When the overall blood volume falls and the blood pressure falls. Low blood pressure is a leading cause of dizziness (21). A rapid heart rate is also a sign of dehydration. The heart rate increases in attempts to maintain and elevate blood pressure. COVID-19 is flagged rejects by one's immune system and they are marked for destruction. Dehydration reduces the overall volume of blood and lymphatic fluids that are integral in a healthy immune system response. Dehydration and inflammation cause Vol 1 Iss 1 further impairment of one's immune system and can contribute to what's called autoimmune diseases (37). If an individual has an autoimmune disease, own immune system attacks healthy cells by mistake. Often, the first symptoms of an autoimmune disorder are fatigue, muscle aches and a low fever which happens during Islamic fasting. Hunger is a major side effect of dehydration as well (22-35).

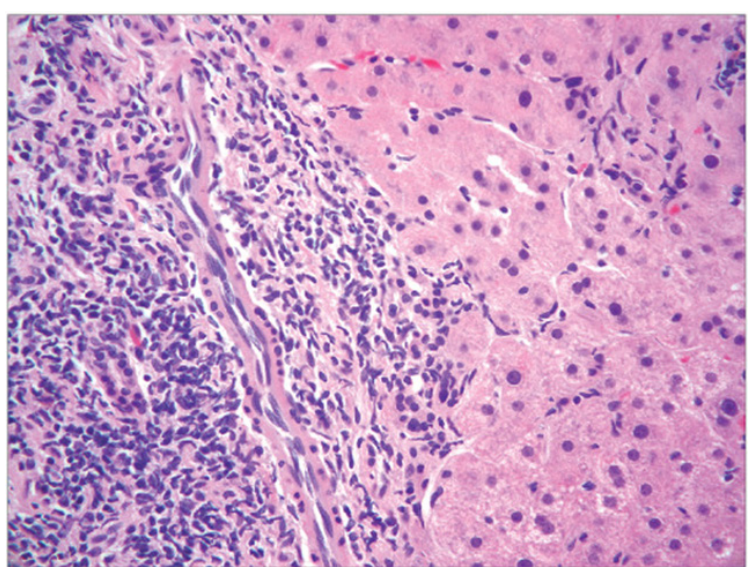

Inflammatory Cell During Dehydration

Out of a total water volume in our body of approximately 50 liters (It accounts for 50-70 percent of body weight), we lose at least 2 liters of water a day from normal daily body maintenance (36). Water losses via the skin can range from 0.3 liters per hour in sedentary conditions to 2.0 liters per hour in high activity in the heat. Water intake requirements range from 2.5 liters to slightly over 3 liters per day in adults under normal conditions, and can reach up to 6 liters per day in extremes of heat and activity (37). Simply sitting in a hot climate can cause the body to lose at least 5 liters of water per day. Dehydration appears to have a negative impact on physical performances that are longer than 30 seconds in duration. Exercise performance is impaired even when an individual is dehydrated by as little as $2 \%$ of body weight. Even though there is no significant negative impact on tasks lasting less than 15 seconds in duration, a state of proper hydration is suggested to be maintained during all physical activities (38).

Histamine formation and release is directly connected to the concentration and viscosity of internal solutions (39-40). Pain results from local chemical changes in the area surrounding the nerve. When water is not present to clear the cellular metabolic waste, it builds up injuring the surrounding tissues. Histamine release can also because symptoms associated with asthma and allergic reactions (41-44).

\section{Dehydration Dampen Metabolism and Chronic Inflammation} Proper metabolism is dependent on chemical reactions that critically depend on water. The flow of water through the cell membrane and mitochondria creates energy that is stored in the form of adenosine triphosphate (ATP). The hydrogen and oxygen molecules from water $\left(\mathrm{H}_{2} \mathrm{O}\right)$ are used by an enzyme called ATP Synthase to convert the ADP to ATP (45). The mitochondria produce less ATP if there is less intracellular water (46). When a cell does not have enough energy to repair itself, the cell breaks down or ruptures. When it ruptures, enzymes are released that 
cause inflammation and damage to adjacent cells and tissues (47). Water is important for clearing out toxins, otherwise chronic inflammation develops within the cells which eventually spills over into the blood vessels and the rest of the body. (45-47) All above statements can be briefly shown in picture (2):

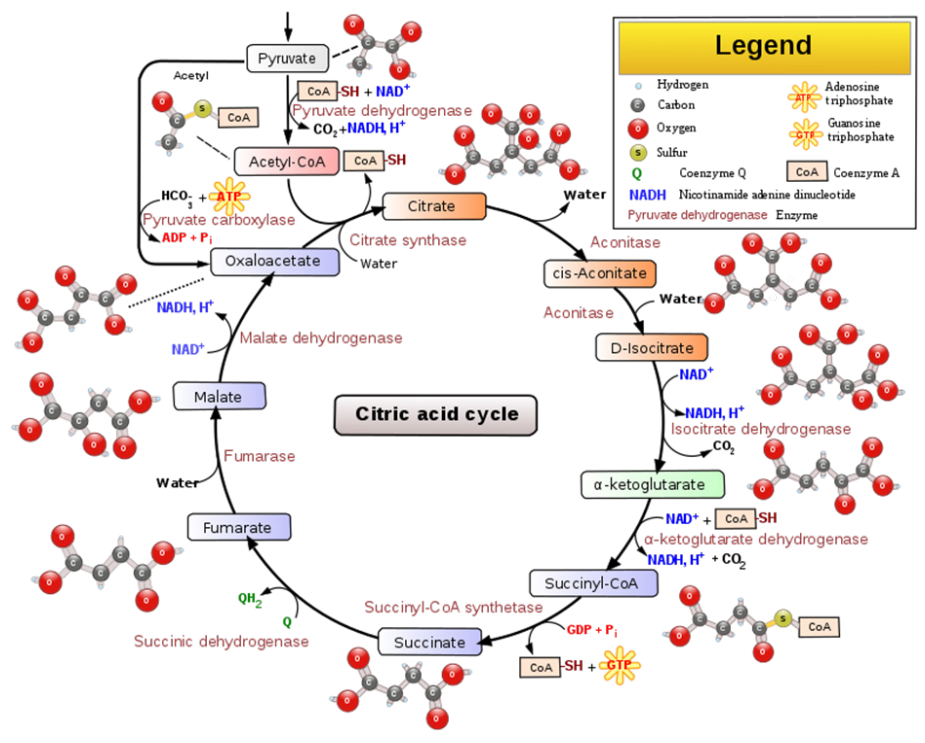

Picture 2: Citric acid cycle.

Low Glucose and water intake during Islamic Fasting contribute to citric acid cycle (CAC) or TCA cycle (tricarboxylic acid cycle) and Acetyl-CoA malfunction since Acetyl-CoA is a molecule that participates in many biochemical reactions in protein, carbohydrate and lipid metabolism. Its main function is to deliver the acetyl group to the citric acid cycle to be oxidized for energy production and reducing the ATP and enough energy for the cell to act properly.

\section{Dehydration can cause high blood pressure}

The renin-angiotensin system is activated to retain water and promote the absorption of salt in the presence of dehydration. It also tightens the capillary beds and overall vascular system until all tissues are well-hydrated. Tightening the vessels increases the pressure within the vessels resulting in a condition known as hypertension. With any stress, the body uses water to break down protein, glycogen, and fats to create energy. If there is pre-existing kidney damage, the kidneys have to work harder to filter the blood which causes greater kidney damage. If this process continues over years, the result can be kidney failure (48).

\section{- A picture of a hydrated cell and a dehydrated cell}
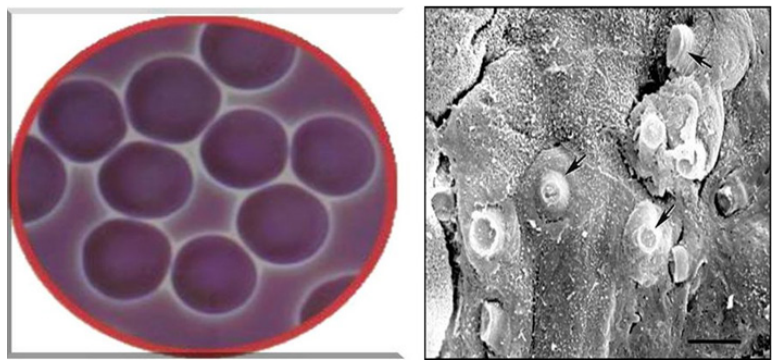

Picture 3: Hydrated Blood Cell and Dehydrated Blood Cell.

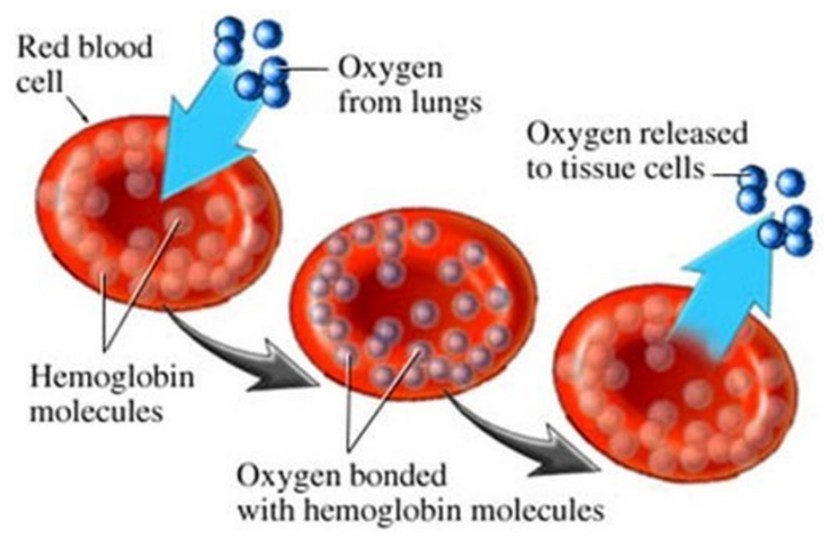

Picture 4: Possible Causes of High or Low Red Blood Cell Count. Islamic Fasting decreases the blood count, reducing oxygen absorption and oxygen releasing to tissue cells (16-18).

\section{Conclusion}

The main reasons which influences the enhance of epidemic of SARS-CoV-2 during Islamic fasting are: Dehydration (Due to not eating water in a long period of time) of the body and specially cells, reducing the metabolism of the body which is controlled by mitochondria of eukaryotic cells, Dehydration causes inflammation and increasing ROS and RNS in human cells and cause immunodeficiency. Dehydration also releases Histamine formation that directly connected to the concentration and viscosity of internal solutions. Pain results from local chemical changes in the area surrounding the nerve. When water is not present to clear the cellular metabolic waste, it builds up injuring the surrounding tissues. Histamine release can cause symptoms associated with asthma and allergic reactions. Dehydration makes the mitochondria produce less ATP if there is less intracellular water. When a cell does not have enough energy to repair itself, the cell breaks down or ruptures. When it ruptures, enzymes are released that cause inflammation and damage to adjacent cells and tissues. The renin-angiotensin system is activated to retain water and promote the absorption of salt in the presence of dehydration. It also tightens the capillary beds and overall vascular system until all tissues are well-hydrated. Tightening the vessels increases the pressure within the vessels resulting in a condition known as hypertension. Dehydration reduces the overall volume of blood and lymphatic fluids that are integral in a healthy immune system response. Overall. Islamic Fasting lower metabolism, causes immunodeficiency, asthma (due to Bohr Effect) and allergic reactions which makes the individual contaminate COVID-19 faster and easier. Islamic Fasting is not recommended during the pandemic of SARS-CoV-2.

\section{References}

1. Fasting (Al Siyam) - IJصsle -. el Bahay el Kholi. 1998;18.

2. Islam, Andrew Egan. 2002;24.

3. Dubai, Andrea Schulte-Peevers 2010;189.

4. Ramadan in the Farthest North. Saudi Aramco World. 2015.

5. How Long Muslims Fast for Ramadan Around the World. Huffingtonpost.co/ 31 July 2014 and article "Fasting Hours of Ramadan 2014" -Onislam.net / 29 June 2014 and article "The 
true spirit of Ramadan" -Gulfnews.com /31 July 2014.

6. Imam Mohamad Jebara "The fasting of Ramadan is not meant to punish" https://ottawacitizen.com/opinion/columnists/ jebara-the-fasting-of-ramadan-is-not-meant-to-punish

7. Kassam, Ashifa. Arctic Ramadan: fasting in land of midnight sun comes with a challenge. The Guardian. 2016.

8. Bukhari-Ibn-Ismail, AbdAllah-Muhammad. Sahih Bukhari Book 031 (The Book of Fasting), Hadith 125. hadithcollection. com.

9. Jane I Smith. Islam in America. Columbia University Press. 2010;15.

10. Edward Hotaling. Islam Without Illusions: Its Past, Its Present, and Its Challenge for the Future. Syracuse University Press, 2003;57.

11. Abu Dawud-Ibn-Ashath-AsSijisstani, Sulayman. Sunan Abu-Dawud - (The Book of Prayer) - Detailed Injunctions about Ramadan, Hadith 1370. Center for Muslim-Jewish Engagement of the University of Southern California. 2012.

12. Bukhari-Ibn-Ismail, AbdAllah-Muhammad. Sahih Bukhari Book 031 (The Book of Fasting), Hadith 199. hadithcollection. com. 2012.

13. Cojocaru M, Cojocaru IM, Silosi I, Vrabie CD. Gastrointestinal manifestations in systemic autoimmune diseases. Maedica (Buchar), 2011;6(1):45-51.

14. Zielinski MR, Systrom DM, Rose NR. Fatigue, Sleep, and Autoimmune and Related Disorders. Front Immunol, 2019;10:1827.

15. Dmitrieva NI, Burg MB. Elevated sodium and dehydration stimulate inflammatory signaling in endothelial cells and promote atherosclerosis. PLoS One, 2015;4:10(6):e0128870.

16. Chen L, Deng H, Cui H, Fang J, Zuo Z, et al. Inflammatory responses and inflammation-associated diseases in organs. Oncotarget, 2017;9(6):7204-7218.

17. Chen L, Deng H, Cui H, Fang J, Zuo Z, et al. Inflammatory responses and inflammation-associated diseases in organs. Oncotarget, 2017;9(6):7204-7218.

18. Popkin BM, D’Anci KE, Rosenberg IH. Water, hydration, and health. Nutr Rev, 2010;68(8):439-458.

19. Hilliard L, Colafella K, Bulmer L. et al. Chronic recurrent dehydration associated with periodic water intake exacerbates hypertension and promotes renal damage in male spontaneously hypertensive rats. Sci Rep, 2016;6:33855.

20. Ruth Werner. A massage Therapist Guide to Pathology (4th ed.). Wolters Kluwer. ISBN 2009;978-0781769198.

21. Wolfgang $\mathrm{H}$ Vogel, Andreas Berke. Brief History of Vision and Ocular Medicine. Kugler Publications, 2009;97:ISBN 978-906299-220-221.

22. Carol Porth. Essentials of pahtophysiology: concepts of altered health states. Hagerstown, MD: Lippincott Williams \& Wilkins, 2007;270.ISBN 978-0-7817-7087-3.

23. Dormandy, Thomas. The worst of evils: man's fight against pain. New Haven, Conn: Yale University Press, 2006;22. ISBN 978-0-300-11322-8.

24. Simon Herrington. Muir's Textbook of Pathology (15th ed.). CRC Press, 2014;59. ISBN 978-1444184990.

25. Ferda Cevikbas, Cordula Kempkes, Timo Buhl, Christian Vol 1 Iss 1
Mess, Joerg Buddenkotte, et al. Carstens, E.; Akiyama, Tasuku (eds.). Itch: Mechanisms and Treatment. Frontiers in Neuroscience. Boca Raton (FL): CRC Press/Taylor \& Francis, 2014;ISBN 9781466505438. PMID 24830021.

26. George H Caughey. Mast cell tryptases and chymases in inflammation and host defense. Immunological Reviews, 2007;217(1):141-154.

27. George H Caughey. Mast cell proteases as pharmacological targets. European Journal of Pharmacology. Pharmacological modulation of Mast cells and Basophils, 2016;778:44-55.

28. Libby P. Inflammation in atherosclerosis. Nature, 2002;420(6917):868-874.

29. Wiedermann U, Vitamin A deficiency increases inflammatory responses. Scand J Immunol, 1996;44(6):578-584.

30. Hargrave B.Y, Tiangco D.A, Lattanzio F.A, Beebe S.J. Cocaine, not morphine, causes the generation of reactive oxygen species and activation of NF- $\mathrm{KB}$ in transiently cotransfected heart cells". Cardiovasc Toxicol, 2003;3(2):141-151.

31. Montiel-Duarte C, Ansorena E, López-Zabalza M.J, Cenarruzabeitia E, Iraburu M.J. Role of reactive oxygen species, glutathione and NF- $\mathrm{kB}$ in apoptosis induced by 3,4-methylenedioxymethamphetamine ("Ecstasy") on hepatic stellate cells. Biochem Pharmacol, 2004;67(6):1025-1033.

32. Hendrik Ungefroren, Susanne Sebens, Daniel Seidl, Hendrik Lehnert, Ralf Haas. Interaction of tumor cells with the microenvironment. Cell Communication and Signaling, 2011;9(18).

33. Coussens L.M, Werb Z. Inflammation and cancer. Nature, 2002;420(6917):860-867.

34. Gunn L, Ding C, Liu M, Ma Y, Qi C, et al. Opposing roles for complement component $\mathrm{C} 5 \mathrm{a}$ in tumor progression and the tumor microenvironment. Journal of Immunology, 2012;189(6):2985-2994.

35. Copland JA, Sheffield-Moore M, Koldzic-Zivanovic N, Gentry S, Lamprou G, et al. "Sex steroid receptors in skeletal differentiation and epithelial neoplasia: is tissue-specific intervention possible?". BioEssays, 2009;31(6):629-641.

36. Kamler E. Parent-egg-progeny Relationships in Teleost Fishes: An Energetics Perspective. Rev Fish Biol Fisheries, 2005; 15:399.

37. Hooper L, Bunn D, Jimoh FO, Fairweather-Tait SJ. Water-loss dehydration and aging. Mech Ageing Dev, 2014;136-137:50-8.

38. Edward W. Carlton MBChB, Martin Than MBBS, Louise Cullen MBBS, Ahmed Khattab PhD, Kim Greaves MD. Chest Pain Typicality' in Suspected Acute Coronary Syndromes and the Impact of Clinical Experience.

39. Goldstein DJ, Halperin JA. Mast cell histamine and cell dehydration thirst. Nature, 1977;19:267(5608):250-2.

40. Millard-Stafford M, Wendland DM, O'Dea NK, Norman TL. Thirst and hydration status in everyday life. Nutr Rev, 2012;70 Suppl 2:S147-51.

41. White MV. The role of histamine in allergic diseases. J Allergy Clin Immunol, 1990;86(4 Pt 2):599-605.

42. Akagi M. Histamine in the pathogenesis of asthma. Nihon Yakurigaku Zasshi, 1998;111(4):217-22.

43. Kay AB. Mediators of hypersensitivity and inflammatory cells Pages 4 of 5 
in the pathogenesis of bronchial asthma. Eur J Respir Dis Suppl, 1983;129:1-44.

44. Yamauchi K, Ogasawara $M$. The Role of Histamine in the Pathophysiology of Asthma and the Clinical Efficacy of Antihistamines in Asthma Therapy. Int J Mol Sci, 2019;20(7):1733.

45. Jonckheere AI, Smeitink JA, Rodenburg RJ. Mitochondrial ATP synthase: architecture, function and pathology. J Inherit Metab Dis, 2012;35(2):211-25. spatio-temporal organization of mitochondrial F1FO ATP synthase in cristae depends on its activity mode. Biochim Biophys Acta Bioenerg, 2020;1861(1):148091.

47. Lawrence L. Espey. Ovulation as an Inflammatory Reaction-A Hypothesis. Biology of Reproduction, 1980;22:73-106.

48. Aburto NJ, Ziolkovska A, Hooper L, Elliott P, Cappuccio FP, et al. Effect of lower sodium intake on health: systematic review and meta-analyses. BMJ, 2013;346:f1326. 